\title{
Cultivation of Flammulina velutipes mushroom using various agro-residues as a fruiting substrate
}

\author{
Nooraishah Harith(1) $^{(1)}$ Noorlidah Abdullah(1) and Vikineswary Sabaratnam ${ }^{(1)}$ \\ (1)University of Malaya, Faculty of Science, Institute of Biological Sciences, Mushroom Research Centre, 50603 Kuala Lumpur, Malaysia. \\ E-mail: nooraishah_harith@yahoo.com, noorlidah@um.edu.my, viki@um.edu.my
}

\begin{abstract}
The objective of this work was to evaluate the feasibility of different agro-residues as a carbon source in the fruiting substrates of Flammulina velutipes mushroom and the effect of supplementation with the nitrogen sources spent brewer's yeast and rice bran. The following fruiting substrates were evaluated: rubber wood sawdust (SD), paddy straw (PS), palm empty fruit bunches (EFB), and palm-pressed fiber (PPF). Cultivation was done on each agro-residue, based on formulations consisting of two substrates at the ratios of 3:1, 1:1, and 1:3. Mycelial growth rate and basidiocarp yield were evaluated. The best fruiting substrates were PS+EFB (25:75), PS+PPF (50:50), and PPF (100), with biological efficiency of 185.09 $\pm 36.98,150.89 \pm 50.35$, and $129.06 \pm 14.51 \%$, respectively. No significant effects of supplementation with rice bran and spent yeast were observed on mycelial growth rate and biological efficiency. The cultivation of $F$. velutipes on oil palm wastes does not require additional nitrogen sources.
\end{abstract}

Index terms: biological efficiency, golden needle mushroom, mycelial growth, oil palm waste, paddy straw.

\section{Cultivo do cogumelo Flammulina velutipes com uso de diferentes resíduos agrícolas como substrato de frutificação}

\begin{abstract}
Resumo - O objetivo deste trabalho foi avaliar a viabilidade do uso de diferentes resíduos agrícolas como fonte de carbono nos substratos de frutificação do cogumelo Flammulina velutipes e o efeito da suplementação com as fontes de nitrogênio levedura de cerveja fermentada e farelo de arroz. Foram avaliados os seguintes substratos de frutificação: serragem de seringueira (SS), palha de arroz (PA), cachos de frutos vazios da palma (CFV) e fibra prensada da palma (FP). O cultivo foi realizado em cada um dos resíduos, baseado em formulações que consistiram de dois substratos, nas proporções de 3:1, 1:1 e 1:3. Foram avaliadas a taxa de crescimento micelial e a produção de basidiocarpo. Os melhores substratos de frutificação foram PA+CFV (25:75), PA+FP (50:50) e FP (100), com eficiência biológica de $185,09 \pm 36,98,150,89 \pm 50,35$ e $129,06 \pm 14,51 \%$, respectivamente. Não foram observados efeitos significativos da suplementação com farelo de arroz e levedura fermentada na taxa do crescimento micelial e na eficiência biológica. O cultivo de F. velutipes sobre resíduos de óleo de palma não necessita de fontes de nitrogênio adicionais.
\end{abstract}

Termos para indexação: eficiência biológica, cogumelo de agulha de ouro, crescimento micelial, resíduos de óleo de palma, palha de arroz.

\section{Introduction}

Most of the mushrooms in the Malaysian market are imported from China. Flammulina velutipes (Curtis) Singer, commonly known as golden needle mushroom, is one of the main imported mushrooms, mostly from Taiwan, China and Korea. In 1997, F. velutipes ranked fifth in the total worldwide production of edible mushrooms, with China, Japan, Korea, and Taiwan as the leading producers (Kües \& Liu, 2000). The mushroom is available either fresh or canned, but the fresh mushroom is preferred by many.
In Malaysia, the production of golden needle mushrooms by growers is still insufficient and inefficient. Local mushroom growers face two major obstacles: firstly, the limited supply of sawdust, mostly due to competition from other industries; and secondly, the fact that sawdust supplies are often mixed with chemicals used in the processing industry. The tainted supply of sawdust affects mushroom growth and causes low yield, a high percentage of contamination, and unsynchronized flushing patterns.

Paddy is one of Malaysia's major crops, with a production of 2,464,831 tons in 2010 (Perangkaan 
Ekonomi Malaysia, 2011). Huge amounts of paddy straw are produced seasonally as solid waste. The use of paddy straw as an alternative substrate for mushroom growing is necessary to solve the environmental pollution problems associated with open-field burning and soil incorporation. Oil palm (Elaeis guineensis) is a major commodity in Malaysia, with $7.84 \mathrm{Mg} \mathrm{ha}^{-1}$ of fresh fruit bunches produced in January-June 2012 (Malaysian Palm Oil Board, 2012). Empty fruit bunches are the major component of all solid waste produced from the palm oil industry. This fibrous material shows high potential to be used as a mushroom growing substrate, without any further treatment, for Auricularia polytricha (Abd Razak et al., 2012) and Pleurotus sajor-caju (Muhamad et al. 2008). Another waste generated is palm-pressed fiber that contains a higher percentage of fiber and lignin, which also makes it a good substrate for mushroom cultivation of, for example, P. sajor-caju (Amal et al., 2008).

Nitrogen sources worth investigating include: rice bran, a by-product of the rice milling process, popularly used as a nitrogen supplement for many edible mushrooms in Asia (Goldammer, 2008); and spent yeast, which is derived from the brewery industry and contains high levels of protein and vitamin $\mathrm{B}$.

A novel substrate formulation using these by-products should be developed and optimized for high-yield production of $F$. velutipes before transferring the technology to mushroom growers. The availability and low cost of providing those agro-residues could be relevant for growers to make a high profit from mushroom production.

The objective of this work was to evaluate the feasibility of different agro-residues as a carbon source in the fruiting substrates of Flammulina velutipes and the effect of nitrogen source supplementation with spent brewer's yeast and rice bran.

\section{Materials and Methods}

The $F$. velutipes strain (KUM60375) used in the experiment was obtained from the Culture Collection of the Mushroom Research Centre, University of Malaya. Alginate-immobilized mycelium was used to replace the grain spawn. Mycelium of $F$. velutipes was grown on malt extract agar (MEA) supplemented with $0.5 \mathrm{mg} \mathrm{L}^{-1}$ 6-benzylaminopurine (BAP) and $0.5 \mathrm{mg} \mathrm{L}^{-1} \beta$-indole acetic acid (IAA) for one week.
Alginate-immobilized mycelium was prepared by mixing mycelial disc with malt extract (ME) media containing alginic acid, and then placed in $0.25 \mathrm{~mol} \mathrm{~L}^{-1}$ calcium chloride $\left(\mathrm{CaCl}_{2}\right)$ to be encapsulated. After $15 \mathrm{~min}$, the immobilized mycelium was rinsed twice with sterile distilled water to remove impurities on the surface of the support material.

The fruiting substrates used were: rubber wood sawdust (SD), paddy straw (PS), palm empty fruit bunches (EFB), and palm-pressed fiber (PPF). The $\mathrm{C}: \mathrm{N}$ ratio of the substrate is often used as a relative reference to characterize compost. All agro-residues were dried and ground to a fine size. To determine a good fruiting substrate for the cultivation of $F$. velutipes, various combinations of agro-residues were tested. The initial selection, consisting of single and of combinations of substrates, was evaluated by preparing the substrates in Petri dishes to determine the radial mycelial growth rate. Each agro-residue (SD, PS, EFB, and PPF) was tested singly for comparison. Six combinations of pairs of substrates, at the ratios of $3: 1(75: 25), 1: 1 \quad(50: 50)$, and $1: 3$ (25:75), were evaluated: SD+PS; SD+EFB; SD+PPF; PS+EFB; PS+PPF; and EFB+PPF. The agro-residues were tested at Consolidated Laboratory (M) Sdn Bhd, Kuala, Lumpur, Malaysia, for carbon and nitrogen content using the furnace and the Kjeldahl method, respectively.

The substrates were thoroughly mixed, and distilled water was added until the substrate was moistened to at least $80 \%$. Calcium carbonate $\left(\mathrm{CaCO}_{3}\right)$, or cooking vinegar, was added to adjust the $\mathrm{pH}$ to 6 , in the range of $0.02-0.10 \mathrm{~g} \mathrm{~g}^{-1}(\mathrm{w} / \mathrm{w})$ and $6 \times 10^{-4}-2.5 \times 10^{-3} \mathrm{~mL} \mathrm{~L}^{-1}$ $(\mathrm{v} / \mathrm{v})$, respectively. The substrate medium $(20 \mathrm{~g})$ was then transferred to Petri dishes $(100 \times 20 \mathrm{~mm})$ and sterilized by autoclaving twice at $121^{\circ} \mathrm{C}$ and 15 psi for 1 hour. Three replicates were performed for each substrate formulation. After cooling to room temperature, the substrates were inoculated with a bead of immobilized mycelium. Inoculated substrate was incubated at $25^{\circ} \mathrm{C}$ to be colonized by the mycelium. Mycelial growth rate ( $\mathrm{mm}$ per day) was measured. Results were evaluated by one-way analysis of variance (Anova) using the Minitab 14 statistical software (Minitab, State College, PA, USA).

To estimate mushroom yield, six formulations that supported the highest radial mycelial growth 
were selected for cultivation in polypropylene plastic bags $(82 \times 322 \mathrm{~mm})$. Substrate medium was filled into plastic bags separately to a height of $10 \mathrm{~cm}$, and the weight was recorded. Three replicates were performed for each substrate medium. The bags were then capped and sterilized twice in an autoclave at $121^{\circ} \mathrm{C}$ and 15 psi for 1 hour. When cooled to room temperature, the bags were inoculated with three beads of mycelium inoculum and incubated at an ambient temperature of $25 \pm 2^{\circ} \mathrm{C}$ until fully colonized. Mycelium extension was measured daily in $\mathrm{mm}$. To induce fruiting, the cap was removed, and the top of the bag was folded down and the surface was raked to a depth of $2 \mathrm{~cm}$. The bags were subsequently placed in an incubator at $8^{\circ} \mathrm{C}$ with a humidity of $60-70 \%$ to stimulate primordium formation. Once primordium had formed, the temperature was increased to $15^{\circ} \mathrm{C}$ until the stipe was approximately $2 \mathrm{~cm}$ in length. When the stipes had elongated to within 2 to $3 \mathrm{~cm}$ from the substrate, paper was placed around the bag to form a cylindrical shape. The paper was removed when the basidiocarps had matured sufficiently. The basidiocarps were then harvested and the yield was recorded. Biological efficiency (BE) was determined using the formula: BE $(\%)=[($ weight of fresh basidiocarps/weight of dry substrate $) \times 100$ ].

Concerning the effects of rice bran (RB) and spent yeast (SY) supplements on the mycelial growth rate and the production of $F$. velutipes basidiocarps, three formulations consisting of PPF (100), PS+EFB (25:75), and PS+PPF (50:50) were selected, based on their high biological efficiency. The concentration of the nitrogen source was measured as a percentage of the total weight of the fruiting substrate. The substrate $\mathrm{pH}$ was fixed at $\mathrm{pH} 6$. The concentration of $\mathrm{RB}$ and SY was assigned using a $2 \times 2$ full factorial experimental design to establish the mathematical relationships and to represent how the mycelial growth rate depends on the percentage of $\mathrm{RB}$ and SY supplementation. Experimental data for each formulation were fitted to a second-order polynomial of the form shown in the equation below. The model consisted of main and interaction terms for a single factor and between two different factor effects, respectively. One response under investigation was mycelial growth in mm per day. Two factors (nitrogen sources) effective in response were chosen, namely RB and SY. For each factor, two different levels were set, which corresponded to low (5\%) and high (20\%) treatments. The non-supplemented substrates were used as controls. Mycelium extension was measured daily in $\mathrm{mm}$, and biological efficiency was determined in percentage.

The main effect was calculated as the mean change in mycelial growth rate when the concentration of one of the supplements was modified from low to high treatments. A Pareto chart of the effect of mycelial growth rate was used to compare the relative magnitude and the statistical significance of both main $(\mathrm{RB}$ and $\mathrm{SY})$ and interaction $(\mathrm{RB} \times \mathrm{SY})$ effects, at $5 \%$ probability. A main effect plot was also used to show the consistent difference between the concentrations of a factor, using the equation: $\mathrm{y}=\mathrm{b}_{0}+\mathrm{b}_{1} \mathrm{x}_{1}+\mathrm{b}_{2} \mathrm{x}_{2}+\mathrm{b}_{11} \mathrm{x}_{1}^{2}+\mathrm{b}_{22} \mathrm{x}_{2}^{2}+\mathrm{b}_{12} \mathrm{x}_{1} \mathrm{x}_{2}$, in which $\mathrm{y}$ is the estimated response; $\mathrm{b}_{0}$ is a constant; $\mathrm{b}_{1}$ are the coefficients for each term; and $\mathrm{x}_{1}$ are the factors in coded values.

One-way Anova was used to analyze the data to establish significant differences between the means, at $5 \%$ probability. Calculations were performed using the Minitab 14 statistical software (Minitab, State College, PA, USA).

\section{Results and Discussion}

Flammulina velutipes has the ability to degrade all lignocellulosic formulations either individually or in combination (Table 1) and supported mycelial growth. Sharma et al. (2009) reported studies on the use of paddy straw, wheat straw, maize straw, cotton seed hulks, and coffee husk as the fruiting substrate of $F$. velutipes. However, no study has been conducted using palm oil by-product residues as a fruiting substrate for $F$. velutipes production. Empty fruit bunches and palm-pressed fiber have been used as fruiting substrates for $P$. sajor-caju (Amal et al., 2008; Muhamad et al., 2008), and both could be potentially used as a fruiting substrate for A. polytricha (Abd Razak et al., 2012).

The results show that PS, EFB, and PPF contained $77.4 \%$ carbon and $0.7 \%$ nitrogen, $89.71 \%$ carbon and $0.36 \%$ nitrogen, and $84.25 \%$ carbon and $0.6 \%$ nitrogen, respectively. SD contained $85.25 \%$ carbon and $0.9 \%$ nitrogen. This shows that the carbon and nitrogen percentages of PS, EFB, and PPF were on par with that of SD, indicating that these agro-residues 
have great potential to be used as a fruiting substrate for $F$. velutipes. Based on these values, the $\mathrm{C}: \mathrm{N}$ ratios of the formulated substrates used in the present study ranged from 94 to 250 and exhibited mycelial growth rates from 4.6-7.2 $\mathrm{mm}$ per day (Table 1). The formulated substrates with $\mathrm{C}: \mathrm{N}$ ratios ranging between 100-125 showed higher mycelial growth rates of 6.8-7.0 mm per day. However, a very weak negative correlation between the $\mathrm{C}: \mathrm{N}$ ratio and the mycelial growth rate was found.

PPF (6.64 $\pm 0.40 \mathrm{~mm}$ per day) showed highest mean radial mycelial growth rate, which was nonsignificant when compared with EFB (6.17 $\pm 0.39 \mathrm{~mm}$ per day) (Table 1). PS showed the lowest growth rate, of $4.60 \mathrm{~mm}$ per day; however, when combined with other substrates, PS significantly supported a higher mycelial growth rate. This might be due to the low carbon content $(77.4 \%)$ and high nitrogen content

Table 1. Effect of carbon sources (mean \pm standard deviation) as fruiting substrate on the radial mycelial growth rate of Flammulina velutipes ${ }^{(1)}$.

\begin{tabular}{lccc}
\hline $\begin{array}{l}\text { Substrate } \\
\text { formulation }\end{array}$ & $\begin{array}{c}\text { Ratio mixture by } \\
\text { weight (\%) }\end{array}$ & $\begin{array}{c}\text { C:N } \\
\text { ratio }\end{array}$ & $\begin{array}{c}\text { Mycelial growth } \\
\text { rate (mm per day) }\end{array}$ \\
\hline SD & 100 & 94.72 & $5.12 \pm 0.32 \mathrm{a}$ \\
PS & 100 & 110.57 & $4.60 \pm 0.09 \mathrm{~b}$ \\
EFB & 100 & 249.19 & $6.17 \pm 0.39 \mathrm{~cd}$ \\
PPF & 100 & 140.42 & $6.64 \pm 0.40 \mathrm{~d}$ \\
SD+PS & $75: 25$ & 95.34 & $6.70 \pm 0.06 \mathrm{~d}$ \\
& $50: 50$ & 101.66 & $6.78 \pm 0.49 \mathrm{de}$ \\
& $25: 75$ & 105.81 & $5.88 \pm 0.12 \mathrm{~cd}$ \\
SD+EFB & $75: 25$ & 115.16 & $6.70 \pm 0.09 \mathrm{de}$ \\
& $50: 50$ & 138.87 & $6.72 \pm 0.04 \mathrm{de}$ \\
SD+PPF & $25: 75$ & 177.18 & $6.35 \pm 0.08 \mathrm{~d}$ \\
& $75: 25$ & 102.41 & $7.20 \pm 0.02 \mathrm{e}$ \\
& $50: 50$ & 113.00 & $6.88 \pm 0.03 \mathrm{de}$ \\
PS+EFB & $25: 75$ & 123.90 & $6.27 \pm 0.06 \mathrm{~d}$ \\
& $75: 25$ & 129.81 & $5.06 \pm 0.26 \mathrm{a}$ \\
& $50: 50$ & 157.66 & $5.06 \pm 0.76 \mathrm{a}$ \\
PS+PPF & $25: 75$ & 192.51 & $6.13 \pm 0.09 \mathrm{~cd}$ \\
& $75: 25$ & 116.34 & $6.33 \pm 0.07 \mathrm{~d}$ \\
& $50: 50$ & 124.35 & $6.84 \pm 0.32 \mathrm{de}$ \\
EFB+PPF & $25: 75$ & 131.02 & $6.47 \pm 0.04 \mathrm{~d}$ \\
& $75: 25$ & 210.36 & $6.46 \pm 0.11 \mathrm{~cd}$ \\
& $50: 50$ & 181.21 & $6.26 \pm 0.16 \mathrm{~cd}$ \\
& $25: 75$ & 158.56 & $6.64 \pm 0.14 \mathrm{de}$ \\
\hline
\end{tabular}

${ }^{(1)}$ Means followed by equal letters, in the columns, do not differ by the one way Anova test, at 5\% probability. Mycelia were grown on substrates consisting of: SD, sawdust; PS, paddy straw; EFB, palm empty fruit bunches; and PPF, palm pressed fiber, in Petri dishes. $\mathrm{n}=3$.
$(0.7 \%)$ in PS. Chang-Ho \& Ho (1979) found that the optimum $\mathrm{C}: \mathrm{N}$ ratio for Volvariella volvacea is about $75-80$, but that ratios between $32-150$ are almost as effective. Plant material with a low C:N ratio decayed more rapidly than those with a high ratio, indicating that mycelial growth rate is related to the bioavailability of nitrogen (Philippoussis, 2009). The combinations of SD with other substrates also showed significantly $(\mathrm{p}<0.05)$ higher mycelial growth rate when compared to SD alone. However, the combination of either PPF or EFB with other substrates lowered the mycelial growth rate. Among the combined substrates, SD+PPF (75:25), PS+PPF (50:50), and SD+PS (50:50) showed higher, but nonsignificant $(\mathrm{p}>0.05)$, growth rates. Based on the $\mathrm{C}: \mathrm{N}$ ratio, EFB (100) showed the largest and SD (100) the lowest C:N ratio, of 249.19 and 94.72, respectively.

The difference in particle size of substrates also contributes to the variation of mycelial growth. In the present study, the SD, EFB, and PPF used were of finer size, compared with PS. PS, being larger in size, shows lowest degradation, besides lignocellulosic composition. PS in combination with other finer substrates increased the rate of mycelial growth (Table 1). The finer the substrates, the higher the water holding capacity, which affects the compactness of the substrate when water is added.

Although the substrate formulations studied showed high mycelial growth rate, these substrates do not necessary produce high basidiocarp yield. Philippoussis et al. (2011) observed a negative correlation between Lentinus edodes mycelial growth rate and biomass yield. Therefore, the selected substrates were chosen based on the higher mycelial growth rate and were evaluated for the production of $F$. velutipes basidiocarps. In accordance with the findings of the present study, Philippoussis (2009) observed that the growth rates of Pleurotus eryngii and $L$. edodes were also positively correlated with the $\mathrm{C}: \mathrm{N}$ ratio. The combination of SD+PS (50:50) showed the highest mycelial growth rate (Table 2). This might be due to the low percentage of lignin in PS; the low molecular weight and soluble carbohydrates of this substrate are easily metabolized by mushroom mycelia (Kurt \& Buyukalaca, 2010). Philippoussis (2009) found that SD contains $37.7-49.5 \%$ cellulose, $10.7-25.0 \%$ hemicelluloses, and 26.1-29.5\% 
lignin; PS contains $22.8-38.4 \%$ cellulose, $17.7-$ $28.5 \%$ hemicelluloses, and $6.4-18.0 \%$ lignin; EFB contains a high range of $45-50 \%$ cellulose, $25-35 \%$ hemicelluloses, and 25-35\% lignin; and PPF consists of $32.4 \%$ cellulose, $38.2 \%$ hemicelluloses, and $20.5 \%$ lignin. Hemicellulose is a polysaccharide with a lower molecular weight than cellulose. The structural complexity of lignin, with its high molecular weight and insolubility, make its degradation difficult (Misson et al., 2009). This is reflected by the lowest mycelial growth rate in PS+EFB (25:75). The yield of basidiocarps varied with the different substrates used.

Concerning the influence of nitrogen availability, substrates with high nitrogen content resulted in a decline in basidiocarp yield. PPF contains the least amount of nitrogen $(0.6 \%)$ and gave high basidiocarp yield $(85.94 \mathrm{~g})$. The combination of SD+PPF $(75: 25)$ showed lower yield $(32.08 \mathrm{~g})$, with a $\mathrm{C}: \mathrm{N}$ ratio of 102. According to Chang \& Miles (2004), a nitrogen compound that resulted in good mycelial growth might not provide a high yield. Furthermore, a high concentration of nitrogen encourages mycelial growth and decreases the formation of the basidiocarp. PS+EFB (25:75) and PS+PPF (50:50) produced the highest biological efficiency (Table 2). All the tested formulation substrates, except SD+PPF (75:25), showed a greater biological efficiency with the amount exceeding 100\%. Lu et al. (1989) reported that $89 \%$ of paddy straw with additives produced a biological efficiency of $50.9 \%$ of $F$. velutipes production. Tang et al. (2001) also observed higher biological efficiency of $90-106 \%$ of $F$. velutipes yield on paddy straw. The production of $F$. velutipes on maize straw as a substrate gave a biological efficiency of $73 \%$ (Ji et al., 2001). On coffee husk as a substrate, the biological efficiency reached about $56 \%$ with two flushes after 40 days and, on coffee spent grounds as a substrate, the biological efficiency reached $78 \%$ (Leifa et al., 2001). Amal et al. (2008) observed the highest yield of $P$. ostreatus using the combination of substrates SD+PPF (50:50), with biological efficiency of $11.3 \%$. Therefore, PPF (100), PS+EFB (25:75), and PS+PPF (50:50) showed great potential for use as an alternative fruiting substrate for $F$. velutipes.

Regarding the effect of RB and SY supplementation on the mycelial growth rate and the production of $F$. velutipes basidiocarps, the main effects of each supplement and the interaction between them were calculated on each selected formulation - PPF (100), PS+EFB (25:75), and PS+PPF (50:50) - that showed high biological efficiencies (Table 2). The fruiting substrate PS+EFB (25:75), supplemented with $\mathrm{RB}+\mathrm{SY}(5.0: 5.0)$ with a $\mathrm{C}: \mathrm{N}$ ratio of 142.6 , exhibited the highest mycelial growth rate of $2.39 \pm 0.18 \mathrm{~mm}$ per day. A significant difference in the mycelial growth rate was observed between supplemented nitrogen and its respective non-supplemented formulations, except for PPF (100) supplemented with $\mathrm{RB}+\mathrm{SY}$ at the concentrations of 5.0:5.0 and 20.0:5.0 (Table 3).

From the validation of a Pareto chart for each fruiting substrate, RB alone shows positive effect on mycelial growth rate as a potential supplement for PS+EFB (25:75) (Figure 1 B) and PS+PPF (50:50) (Figure $1 \mathrm{C}$ ) that exceeded the significance level of $95 \% \quad(\alpha=0.05)$ at 2.23 (x-axis); however, there was no significant effect for PPF (100) (Figure $1 \mathrm{~A}$ ). The interaction of RB+SY also shows significant effect on mycelial growth rate

Table 2. Effect (mean \pm standard deviation) of selected fruiting substrate formulations on the mycelial growth rate, basidiocarp yield, and biological efficiency of Flammulina velutipes ${ }^{(1)}$.

\begin{tabular}{lcccccc}
\hline $\begin{array}{l}\text { Substrate } \\
\text { formulations (\%) }\end{array}$ & $\mathrm{pH}$ & $\begin{array}{c}\text { Dry weight of } \\
\text { substrate }(\mathrm{g})\end{array}$ & $\begin{array}{c}\text { Time for complete } \\
\text { spawn run (days) }\end{array}$ & $\begin{array}{c}\text { Mycelial growth } \\
\text { rate (mm per day) }\end{array}$ & $\begin{array}{l}\text { Total basidiocarp } \\
\text { yield (g per bag) }\end{array}$ & $\begin{array}{c}\text { Biological } \\
\text { efficiency }(\%)\end{array}$ \\
\hline SD+EFB (50:50) & $6.33 \pm 0.04 \mathrm{a}$ & $45.96 \pm 1.76 \mathrm{a}$ & 49 & $1.76 \pm 0.13 \mathrm{~b}$ & $57.91 \pm 19.59 \mathrm{abc}$ & $125.27 \pm 39.68 \mathrm{ab}$ \\
SD+PS (50:50) & $6.76 \pm 0.03 \mathrm{~b}$ & $33.27 \pm 0.82 \mathrm{~b}$ & $44-45$ & $2.05 \pm 0.11 \mathrm{bc}$ & $41.21 \pm 12.20 \mathrm{ab}$ & $123.91 \pm 7.07 \mathrm{ab}$ \\
PS+EFB (25:75) & $6.42 \pm 0.03 \mathrm{c}$ & $35.00 \pm 2.28 \mathrm{~b}$ & 50 & $1.26 \pm 0.07 \mathrm{a}$ & $65.08 \pm 15.24 \mathrm{bc}$ & $185.09 \pm 36.98 \mathrm{~b}$ \\
SD+PPF (75:25) & $5.54 \pm 0.03 \mathrm{~d}$ & $42.93 \pm 2.12 \mathrm{ac}$ & $31-45$ & $1.90 \pm 0.60 \mathrm{~b}$ & $32.08 \pm 5.55 \mathrm{a}$ & $74.41 \pm 9.62 \mathrm{a}$ \\
PS+PPF (50:50) & $5.33 \pm 0.06 \mathrm{e}$ & $39.54 \pm 2.94 \mathrm{c}$ & 50 & $1.25 \pm 0.17 \mathrm{a}$ & $59.02 \pm 18.17 \mathrm{abc}$ & $150.89 \pm 50.35 \mathrm{~b}$ \\
EFB+PPF (25:75) & $5.06 \pm 0.02 \mathrm{f}$ & $55.24 \pm 0.71 \mathrm{~d}$ & 49 & $1.63 \pm 0.07 \mathrm{ab}$ & $41.29 \pm 35.87 \mathrm{ab}$ & $112.00 \pm 9.12 \mathrm{a}$ \\
PPF (100) & $4.71 \pm 0.01 \mathrm{~g}$ & $66.79 \pm 2.97 \mathrm{e}$ & 49 & $1.79 \pm 0.07 \mathrm{ab}$ & $85.93 \pm 6.47 \mathrm{c}$ & $129.06 \pm 14.51 \mathrm{ab}$ \\
\hline
\end{tabular}

${ }^{(1)}$ Means followed by equal letters, in the columns, do not differ by the one-way Anova test, at $5 \%$ probability. Cultivation was done on substrates consisting of: SD, sawdust; PS, paddy straw; EFB, palm empty fruit bunches; and PPF, palm-press fiber, in polypropylene bags. $\mathrm{n}=3$. 
for PS+EFB (25:75) and PS+PPF (50:50). The effect of SY alone on mycelial growth rate was significant for PS+PPF (Figure $1 \mathrm{C}$ ). From the validation of a main effect plot for each fruiting substrate, $5 \%$ concentration of RB supplementation on PS+EFB (25:75) shows higher mean mycelial growth rate of $2.26 \mathrm{~mm}$ per day. For PS+PPF (50:50), RB (20\%) shows higher mean mycelial growth rate of $1.91 \mathrm{~mm}$ per day, whereas SY shows highest rate of $1.88 \mathrm{~mm}$ per day, at $5 \%$. The highest mycelial growth rate of $F$. velutipes was also reported by Ji et al. (2001) on wheat straw supplemented with 5\% wheat bran. In addition, Moonmoon et al. (2011) found the highest mycelium growth of L. edodes when $20 \%$ RB was added to SD fruiting substrate. However, in the present study, the yield of basidiocarps on the supplemented substrates decreased (Table 3). Similar findings were reported by Philippoussis (2009) on P. eryngii mushroom yield. Therefore, an excess of nitrogen might also be a factor affecting basidiocarp yield. In the present study, the supplemented substrates also had a lower biological efficiency when compared with the non-supplemented ones, and different supplement concentrations had no significant effect on biological efficiency. The biological efficiency on the supplemented substrates ranged from $48-138 \%$, which can be considered on par to that of the commercial fruiting substrate, and was of $77 \%$ with $\mathrm{SD}+\mathrm{RB}$ supplementation. Tang et al. (2001) observed that paddy straw supplemented with $10 \%$ rice bran only gave biological efficiency of $76.73 \%$. Therefore, it is economically beneficial for growers to disregard supplementation; however, in terms of nutritional aspects, supplementation is required to improve the production, quality, flavor, and shelf-life of cultivated mushrooms. The present study provides a viable option for the use of oil palm waste in the cultivation of $F$. velutipes for food, as well as for reducing environmental pollution.

Table 3. Effect (mean \pm standard deviation) of the nitrogen source supplements, rice bran (RB) and spent yeast (SY), on the average mycelial growth rate, basidiocarp yield, and biological efficiency of Flammulina velutipes ${ }^{(1)}$.

\begin{tabular}{|c|c|c|c|c|c|c|}
\hline \multicolumn{2}{|c|}{ Nitrogen source (\%) } & \multirow[t]{2}{*}{$\mathrm{C}: \mathrm{N}$} & \multirow{2}{*}{$\begin{array}{l}\text { Average dry weight } \\
\text { of substrate }(\mathrm{g})\end{array}$} & \multirow{2}{*}{$\begin{array}{l}\text { Mycelial growth } \\
\text { rate (mm per day) }\end{array}$} & \multirow{2}{*}{$\begin{array}{l}\text { Total yield } \\
\text { (g per bag) }\end{array}$} & \multirow{2}{*}{$\begin{array}{c}\text { Biological } \\
\text { efficiency (\%) }\end{array}$} \\
\hline $\mathrm{RB}$ & SY & & & & & \\
\hline \multicolumn{7}{|c|}{$\mathrm{SD}(100)$} \\
\hline 20.0 & 0.0 & 75.0 & $50.81 \pm 6.96$ & $1.80 \pm 0.12$ & $39.80 \pm 14.39$ & $77.47 \pm 20.19$ \\
\hline \multicolumn{7}{|c|}{ PS+EFB (25:75) } \\
\hline 0.0 & 0.0 & 192.5 & $35.00 \pm 2.28 \mathrm{a}$ & $1.26 \pm 0.07 \mathrm{a}$ & $65.08 \pm 15.24 \mathrm{~b}$ & $185.09 \pm 36.98 \mathrm{~b}$ \\
\hline 20.0 & 20.0 & 86.7 & $44.94 \pm 2.98 b$ & $2.00 \pm 0.03 b$ & $41.38 \pm 7.52 \mathrm{ab}$ & $92.33 \pm 18.37 \mathrm{a}$ \\
\hline 5.0 & 5.0 & 142.6 & $43.15 \pm 1.33 b$ & $2.39 \pm 0.18 \mathrm{c}$ & $27.81 \pm 9.20 \mathrm{a}$ & $65.91 \pm 22.59 a$ \\
\hline 12.5 & 12.5 & 105.8 & $40.45 \pm 0.63 b$ & $2.06 \pm 0.08 \mathrm{~b}$ & $54.45 \pm 15.57 \mathrm{ab}$ & $134.78 \pm 39.28 \mathrm{ab}$ \\
\hline 20.0 & 5.0 & 110.2 & $56.29 \pm 3.47 \mathrm{c}$ & $1.87 \pm 0.26 \mathrm{~b}$ & $73.88 \pm 18.89 b$ & $129.47 \pm 33.60 \mathrm{ab}$ \\
\hline 5.0 & 20.0 & 101.4 & $44.49 \pm 0.59 \mathrm{~b}$ & $2.12 \pm 0.05 \mathrm{~b}$ & $27.43 \pm 18.50 \mathrm{a}$ & $61.43 \pm 40.98 \mathrm{a}$ \\
\hline \multicolumn{7}{|c|}{ PS+PPF (50:50) } \\
\hline 0.0 & 0.0 & 124.4 & $55.24 \pm 0.71 \mathrm{a}$ & $1.25 \pm 0.17 \mathrm{a}$ & $59.02 \pm 18.17 \mathrm{ab}$ & $150.89 \pm 50.35 b$ \\
\hline 20.0 & 20.0 & 76.8 & $58.11 \pm 2.73 b$ & $1.69 \pm 0.03 b$ & $77.63 \pm 18.16 b$ & $132.90 \pm 26.51 \mathrm{ab}$ \\
\hline 5.0 & 5.0 & 118.0 & $47.35 \pm 5.24 \mathrm{ab}$ & $1.64 \pm 0.14 \mathrm{~b}$ & $72.90 \pm 7.41 \mathrm{~b}$ & $147.54 \pm 23.13 b$ \\
\hline 12.5 & 12.5 & 91.4 & $45.76 \pm 11.60 \mathrm{ab}$ & $1.72 \pm 0.22 b$ & $58.33 \pm 27.95 \mathrm{ab}$ & $138.35 \pm 81.27 \mathrm{ab}$ \\
\hline 20.0 & 5.0 & 95.4 & $50.36 \pm 1.00 \mathrm{ab}$ & $2.13 \pm 0.03 \mathrm{c}$ & $24.02 \pm 2.52 \mathrm{a}$ & $48.10 \pm 5.93 \mathrm{a}$ \\
\hline 5.0 & 20.0 & 87.4 & $49.52 \pm 8.05 \mathrm{ab}$ & $1.67 \pm 0.11 \mathrm{~b}$ & $74.16 \pm 14.56 \mathrm{~b}$ & $137.47 \pm 26.21 \mathrm{ab}$ \\
\hline \multicolumn{7}{|c|}{ PPF (100) } \\
\hline 0.0 & 0.0 & 140.4 & $66.79 \pm 2.97 \mathrm{ab}$ & $1.79 \pm 0.07 \mathrm{a}$ & $85.93 \pm 6.47 \mathrm{c}$ & $129.06 \pm 14.51 \mathrm{a}$ \\
\hline 20.0 & 20.0 & 75.4 & $73.13 \pm 0.58 \mathrm{a}$ & $2.17 \pm 0.50 \mathrm{~b}$ & $55.36 \pm 19.12 \mathrm{ab}$ & $75.88 \pm 27.24 b c$ \\
\hline 5.0 & 5.0 & 112.0 & $61.38 \pm 1.85 \mathrm{~b}$ & $1.99 \pm 0.03 \mathrm{ab}$ & $46.38 \pm 11.43 \mathrm{a}$ & $75.43 \pm 17.38 b c$ \\
\hline 12.5 & 12.5 & 88.7 & $62.34 \pm 1.92 \mathrm{~b}$ & $2.16 \pm 0.02 b$ & $55.31 \pm 2.47 \mathrm{ab}$ & $88.75 \pm 3.66 b c$ \\
\hline 20.0 & 5.0 & 92.5 & $73.10 \pm 4.93 \mathrm{ab}$ & $2.02 \pm 0.13 \mathrm{ab}$ & $69.32 \pm 2.54 b c$ & $95.82 \pm 7.62 \mathrm{~b}$ \\
\hline 5.0 & 20.0 & 84.9 & $66.77 \pm 2.44 \mathrm{ab}$ & $2.22 \pm 0.09 \mathrm{~b}$ & $43.84 \pm 3.23 \mathrm{a}$ & $65.33 \pm 5.02 \mathrm{c}$ \\
\hline
\end{tabular}

${ }^{(1)}$ Means followed by equal letters, in the columns, do not differ by the one-way Anova test, at $5 \%$ probability. Cultivation was done on substrates consisting of: SD, sawdust; PS, paddy straw; EFB, palm empty fruit bunches; and PPF, palm-press fiber, in polypropylene bags. $\mathrm{n}=3$. 

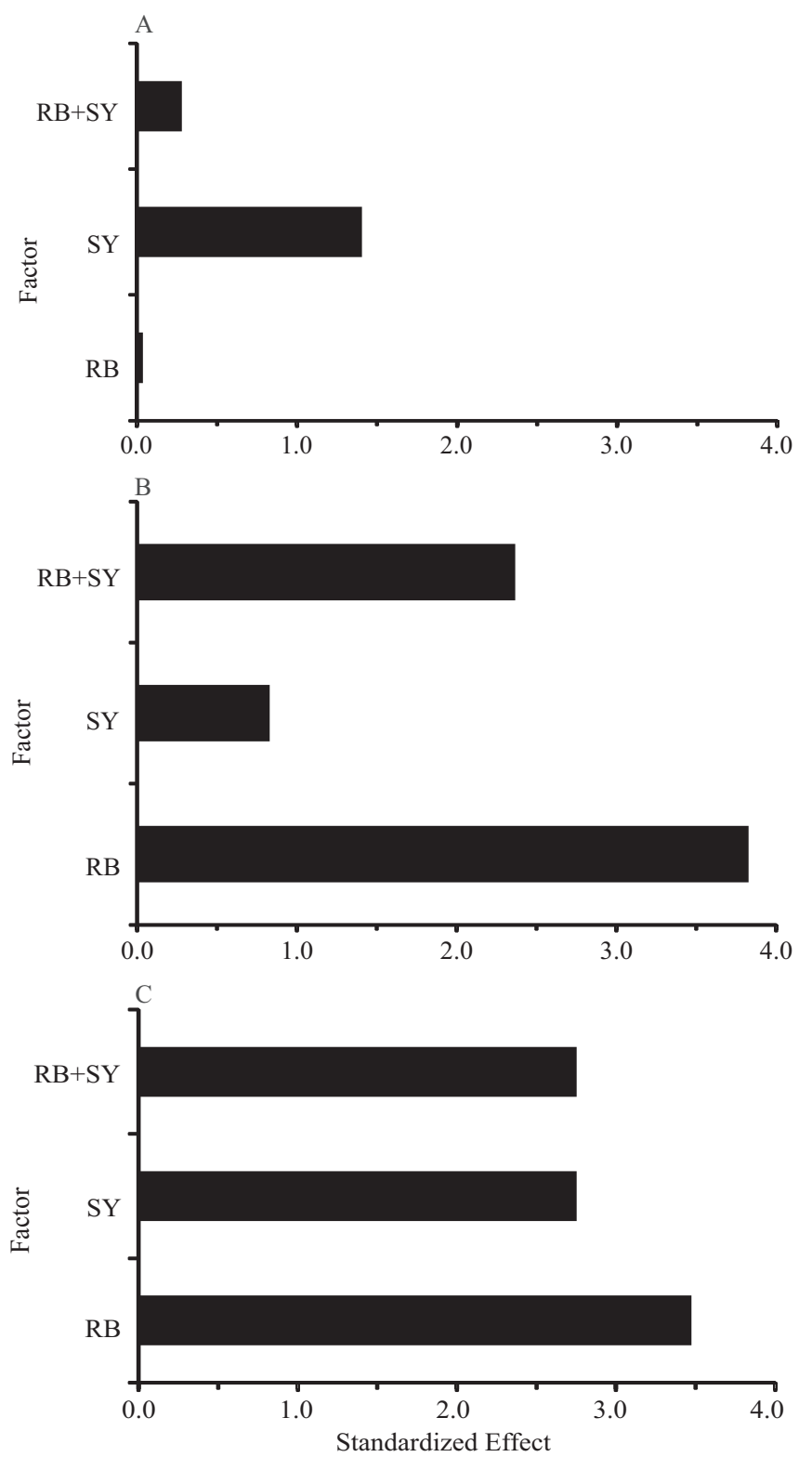

Figure 1. Pareto chart of standardized effects for mycelial growth rate of Flammulina velutipes with different concentrations of rice bran (RB) and spent yeast (SY) supplemented on: A, palm-pressed fiber; B, paddy straw and palm empty fruit bunches (25:75); and C, paddy straw plus palm pressed fiber (50:50). Significant level line of $95 \%$ at 2.23 (x-axis).

\section{Conclusions}

1. The combination of paddy straw and palm empty fruit bunches has potential to be used as a fruiting substrate for Flammulina velutipes, at a ratio of 1:3.
2. The combination of paddy straw and palm-pressed fiber at a ratio of $1: 1$ is the best fruiting substrate.

3 . The cultivation of $F$. velutipes on oil palm wastes does not require additional nitrogen sources.

\section{Acknowledgements}

To University of Malaya, for research grants (PS243/2009C and RP015A-14AFR); and to Mushroom Research Centre and Glami Lemi Biotechnology Research Centre of University of Malaya, for providing research facilities.

\section{References}

ABD RAZAK, D.L.; ABDULLAH, N.; SABARATNAM, V.; KHIR JOHARI, N.M. Comparative study of mycelia growth and sporophore yield of Auricularia polytricha (Mont.) Sacc on selected palm oil wastes as fruiting substrate. Applied Microbiology and Biotechnology, v.97, p.3207-3213, 2012. DOI: 10.1007/ s00253-012-4135-8.

AMAL, N.M.T.; FATHIE, A.Z.; WAN, N.F.M.F.; NOORHAELIZA, A.; ONN, H. The usage of empty fruit bunch (EFB) and palm pressed fibre (PPF) as substrates for the cultivation of Pleurotus ostreatus. Jurnal Teknologi, v.49, p.189-196, 2008.

CHANG, S.-T.; MILES, P.G. Mushrooms: cultivation, nutritional value, medicinal effect and environmental impact. $2^{\text {nd }}$ ed. Boca Raton: CRC Press, 2004. 480p. DOI: 10.1201/9780203492086.

CHANG-HO, Y.; HO, T.M. Effect of nitrogen amendment on the growth of Volvariella volvacea. Mushroom Science, v.10, p.619-628, 1979.

GOLDAMMER, T. The brewer's handbook: a complete book to brewing beer. $2^{\text {nd }}$ ed. San Francisco: Apex Publishers, 2008. 496p.

JI, H.; WANG, Q.; WANG, H.; CHEN, W.J.; ZHU, C.H.; HOU, H.; ZHANG, Z. A fundamental research of mushroom cultivation using maize straw. Edible Fungi of China, v.20, p.10-12, 2001.

KÜES, U.; LIU, Y. Fruiting body production in basidiomycetes. Applied Microbiology and Biotechnology, v.54, p.141-152, 2000. DOI: $10.1007 / \mathrm{s} 002530000396$.

KURT, S.; BUYUKALACA, S. Yield performances and changes in enzyme activities of Pleurotus spp. ( $P$. ostreatus and $P$. sajor-caju) cultivated on different agricultural wastes. Bioresource Technology, v.101, p.3164-3169, 2010. DOI: 10.1016/j. biortech.2009.12.011.

LEIFA, F.; PANDEY, A.; SOCCOL, C.R. Production of Flammulina velutipes on coffee husk and coffee spent ground. Brazilian Archives of Biology and Technology, v.44, p.205-212, 2001. DOI: 10.1590/S1516-89132001000200015.

LU, Q.G.; GUI, Y.W.; TONG, X.I. Mycelium growth and mushroom yield of Flammulina velutipes on different culture media. Jiangsu Agricultural Sciences, v.3, p.26-27, 1989. 
MALAYSIAN PALM OIL BOARD. Monthly FFB yield (tonnes/hectare) Jan-June $2011 \quad$ \& 2012.2012. Available at: <http://bepi.mpob.gov.my/index.php/statistics/ yield/103-yield-2012/485-ffb-yield-january-june-2012.html>. Accessed on: 14 July 2012.

MISSON, M.; HARON, R.; AHMAD KAMARODDIN, M.F.; SAIDINA AMIN, N.A. Pretreatment of empty fruit bunch for lignin degradation. Jurnal Teknologi, v.50, p.89-98, 2009. DOI: 10.11113/jt.v50.178.

MOONMOON, M.; SHELLY, N.J.; KHAN, M.A.; UDDIN, M.N.; HOSSAIN, K.; TANIA, M.; AHMED, S. Effects of different levels of wheat bran, rice bran and maize powder supplementation with sawdust on the production of shiitake mushroom (Lentinus edodes (Berk.) Singer). Saudi Journal of Biological Sciences, v.18, p.323-328, 2011. DOI: 10.1016/j.sjbs.2010.12.008.

MUHAMAD, I.I.; HASSAN, M.F.; MOHAMAD, S.N.H.; TIN, L.C.; SARMIDI, M.R. Production of Pleurotus sajor-caju on sawdust of rubber tree and empty fruit bunch. Journal of Chemical and Natural Resources Engineering, p.14-23, 2008.

PERANGKAAN EKONOMI MALAYSIA. Malaysia economic statistic - time series. 2011. Available at: <http://www.
statistics.gov.my/portal/download_Economics/files/DATA_ SERIES/2011/Penerbitan_Time_Series_2011.pdf>. Accessed on: 15 July 2012.

PHILIPPOUSSIS, A. Production of mushrooms using agro-industrial residues as substrates. In: SINGH nee' NIGAM, P.; PANDEY, A. (Ed.). Biotechnology for agro-industrial residues utilisation. New York: Springer, 2009. p.163-196. DOI: 10.1007/978-1-4020-9942-7_9.

PHILIPPOUSSIS, A.; DIAMANTOPOULOU, P.; PAPADOPOULOU, K.; LAKHTAR, H.; ROUSSOS, S.; PARISSOPOULOS, G.; PAPANIKOLAOU, S. Biomass, laccase and endoglucanase production by Lentinula edodes during solid state fermentation of reed grass, bean stalks and wheat straw residues. World Journal of Microbiology and Biotechnology, v.27, p.285-297, 2011. DOI: 10.1007/s11274-010-0458-8.

SHARMA, V.P.; KUMAR, S.; TEWARI, R.P. Flammulina velutipes, the culinary medicinal winter mushroom. New Delhi: Yugantar Prakashan, 2009. 53p.

TANG, X.N.; BIAN, G.Q.; ZHANG, M.; YANG, H.B.; YU, J.H. Studies on cultivating Flammulina velutipes with Paspalum notatum. Edible Fungi of China, v.20, p.10-12, 2001.

Received on November 11, 2013 and accepted on February 28, 2014 